\title{
Tectonic Environment of the 1999 Chi-Chi Earthquake in Central Taiwan and its Aftershock Sequence
}

Chengsung Wang ${ }^{1, *}$, Tzu-Hua Huang ${ }^{1}$, I-Chin Yen $^{1}$, Su-Long Wang ${ }^{1}$ and Win-Bin Cheng ${ }^{2}$

(Manuscript received 31 March 2000, in final form 30 May 2000)

\begin{abstract}
In the early morning of 21 September, 1999, Taiwan experienced its most powerful inland earthquake (with Richter magnitude 7.3) of the century. The earthquake occurred near the small town of ChimChi in central Taiwan, in an area with a low recent background of seismicity although it is surrounded by belts of high seismicity. It caused an extensive surface ruptures totaling about $100 \mathrm{~km}$ long and a tremendous number of aftershocks. Using seismological and morphological data, we investigate the tectonic environment in central Taiwan and the associated plate structure in the Taiwan region, with emphasis on the cause of the earthquake and its aftershock sequence.

Taiwan island is situated on the northwestern corner of the Philippine Sea plate, where its interaction with the Eurasian plate is complicated. The Philippine Sea plate moves northwestward with respect to the Eurasian plate. The former subducts northwestward, in general, along the Ryukyu trench. However, due to the impediment of its motion, it subducts northward and underthrusts westward in the Taiwan region, with the meridian line of $121.5^{\circ} \mathrm{E}$ being the present western boundary of the active subducting lithosphere. The western boundary is migrating westward, at a rate of about $6 \mathrm{~cm} / \mathrm{y}$, along with the northwestward movement of the Philippine Sea plate. The Philippine Sea plate, like a plow, pushes and uplifts Taiwan island situated on the Asian continental margin, as demonstrated by a seismic wedge to the east of $121^{\circ} \mathrm{E}$. In central Taiwan, there exist two obvious linear belts of frequent earthquakes, almost perpendicular and individually trending NW and NE. These linear belts form the boundaries of a triangular area with low background seismicity in front of the seismic wedge, including the Peikang basement high, an uplifted pre-Miocene basement beneath the Western Coastal Plain and its offshore zone. The Chi-Chi earthquake occurred in a subarea of the triangular area near the vertex, con-
\end{abstract}

${ }^{1}$ Institute of Applied Geophysics, National Taiwan Ocean University, Keelung, 202 Taiwan

${ }^{2}$ Department of Visual Communication Design, Jin-Wen Institute of Technology, Taipei County, Taiwan

${ }^{*}$ Corresponding author address: Prof. Chengsung Wang, Institute of Applied Geophysics, National

Taiwan Ocean University, \#2 Beining Road, Keelung, 202 Taiwan; E-mail: wangcs @mail.ntou.edu.tw 
fined by the seismic belts and the Peikang basement high. The northwestward movement of the subarea has been impeded by the Peikang basement high, and the associated crustal strain energy may have thus been stored, and then released to trigger the Chi-Chi earthquake, the ruptures and the aftershocks.

\section{(Key words: Chi-Chi earthquake, Aftershock sequence, Interaction between plates, Seismicity, Seismic wedge, Tectonic structure)}

\section{INTRODUCTION}

At 1:47 (Taiwan local time) on September 21, 1999, Taiwan was struck by its most powerful inland earthquake of the century. The earthquake killed more than 2,400 people and injured over 11,000. The epicenter was near the small town of Chi-Chi in central western Taiwan. It occurred in a relatively quiet area (Fig. 1), seismologically, and induced a great number of aftershocks, over 20,000 in the first two months. It caused instaneous extensive surface ruptures, with the main rupture about $85 \mathrm{~km}$ long along the north-south trending Chelungpu fault (Fig. 1; Lee et al. 1999a; Lee et al. 1999b). It also caused extensive crustal deformation in the whole central Taiwan area, with the maximum vertical uplift of about 6 meters and horizontal displacement of over 9 meters (e.g., Rau et al. 1999; Lee et al. 1999a, b; Liu et al. 1999; Chung and Shin, 1999). The event represents an episode of vivid mountain building in the Taiwan region, caused by the Philippine Sea plate's northwestward pushing on the continental margin of the Eurasian plate.

In this study, using mainly the hypocentral distribution of earthquakes since 1973 as recorded and located by the Central Weather Bureau Seismological Network (CWBSN, operated by the Seismological Observation Center of the CWB, Taiwan) and the Taiwan Telemetered Seismological Network (operated by the Institute of Earth Sciences, Academia Sinica, Taiwan), we study the tectonic environment of the Chi-Chi earthquake and the aftershock sequence, with emphasis on the associated interaction of the Eurasian and Philippine Sea plates in the Taiwan region.

\section{TECTONIC SETTING}

Mountainous Taiwan island is a part of the anomalous Ryukyu-Taiwan-Luzon arc-trench system around the northwestern corner of the Philippine Sea plate (Figs. 2 and 3), where subductions of opposite polarities exist. The Philippine Sea plate moves northwestward, in general, with respect to the Eurasian plate. It subducts along the Ryukyu trench in the north and along the Philippine trench in the west. The trenches are disconnected in the TaiwanLuzon region, where the northwestward subduction of the Philippine Sea plate is absent. Furthermore, there exists an eastward subduction of the South China Sea lithosphere along the Manila trench to the south of Taiwan. The relationship between the subduction systems in the Taiwan region is still unclear. 


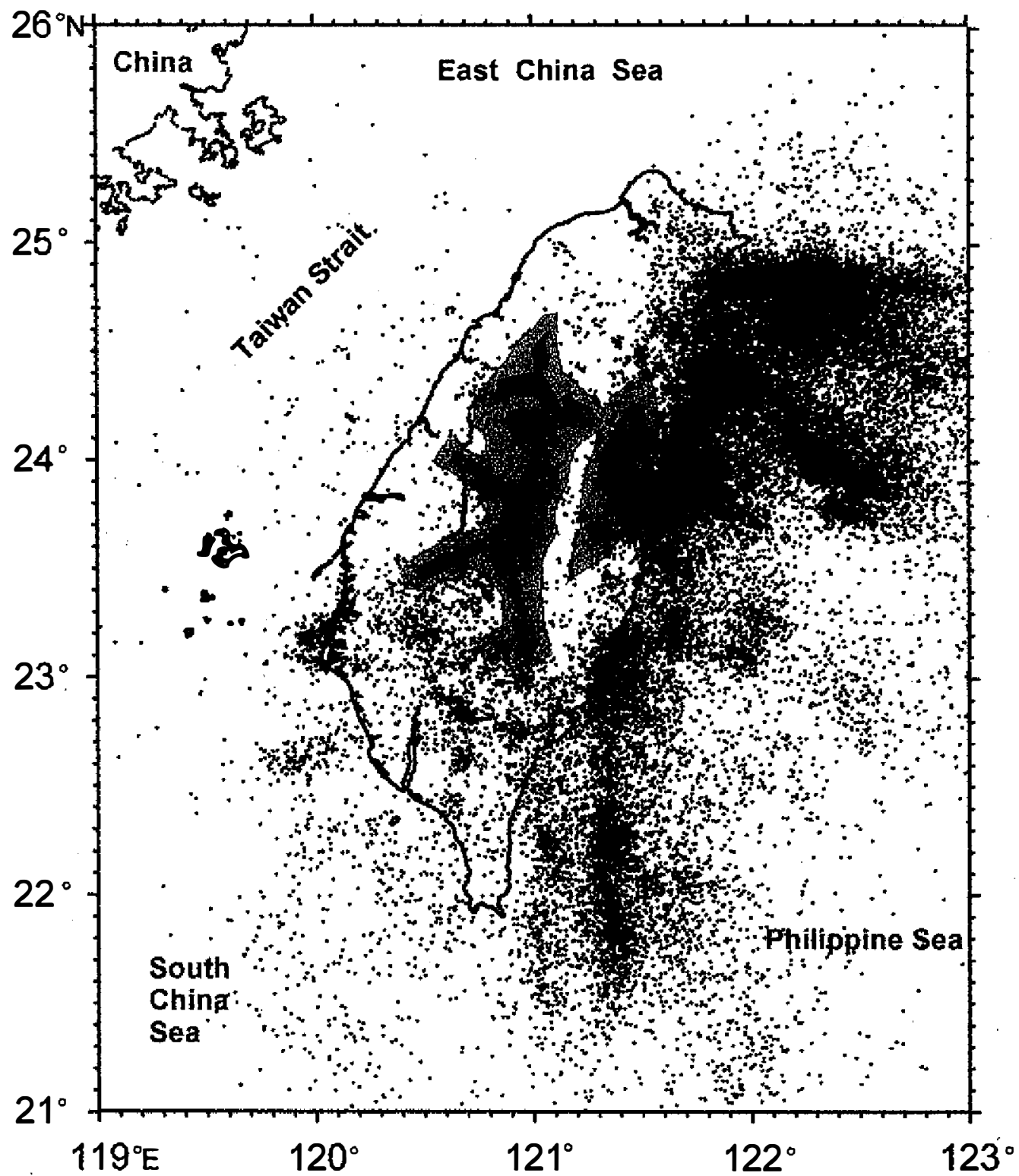

Fig. 1. Epicentral distribution of earthquakes in the Taiwan region since 1973. Dots represent earthquakes with $M \geq 3$ from 1973 to 1999 , prior to the occurrence of the 1999 September 21 Chi-Chi earthquake in central Taiwan (designated by the star). The dark and light shaded areas show the areas with clusters of aftershocks of the Chi-Chi earthquake with $M \geq 3$ and $M \geq 2$, respectively (see the epicentral distribution of aftershocks in Figs. 8 and 9). The curve in western central Taiwan is the Chelungpu fault. 


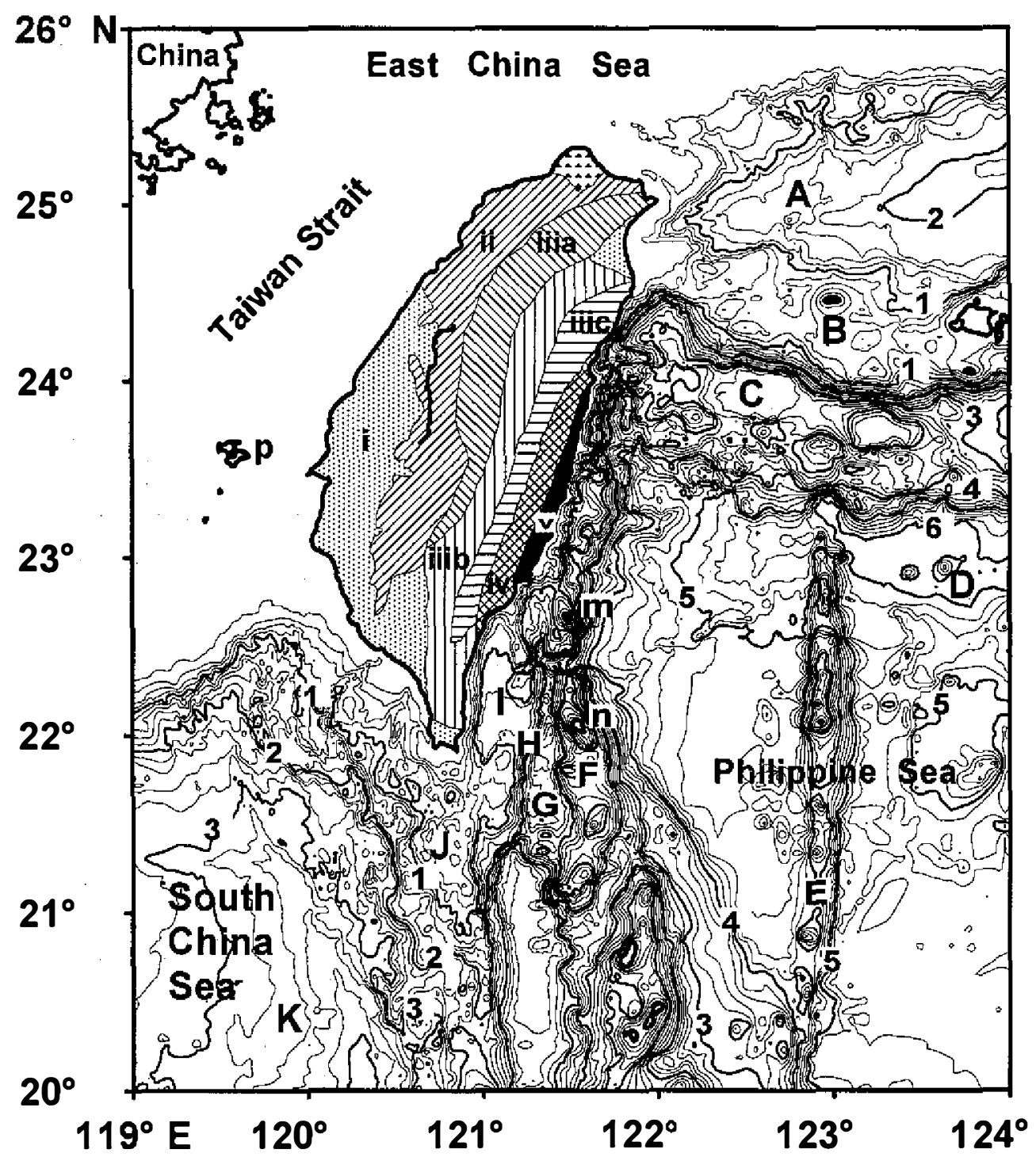

Fig. 2. Structural provinces on Taiwan island (Ho 1986;1988) and its surrounding offshore region. i: Western Coastal Plain; ii: Western Foothills; iiia: Hsueshan Range; iiib: Western Hank of Central Range; iiic: Eastern flank of Central Range; iv: Longitudinal Valley; v: Coastal Range; A: Okinawa trough; B: Ryukyu arc; C: Nan-ao basin (forearc basin of the Ryukyu arc); D: Ryukyu rench; E: Gagua ridge; F: Luzon arc; G: North Luzon Trough; H: Huauing Ridge; I: South Longitudinal Trough; J: Hengchun Ridge; K: Manila ench; m: Lutao (island); n: Lanhsu (island); p: Penhu islands. The curve in western central Taiwan is the Chelungpu fault, about $85 \mathrm{~km}$ long, caused by the Chi-Chi earthquake in central Taiwan. 


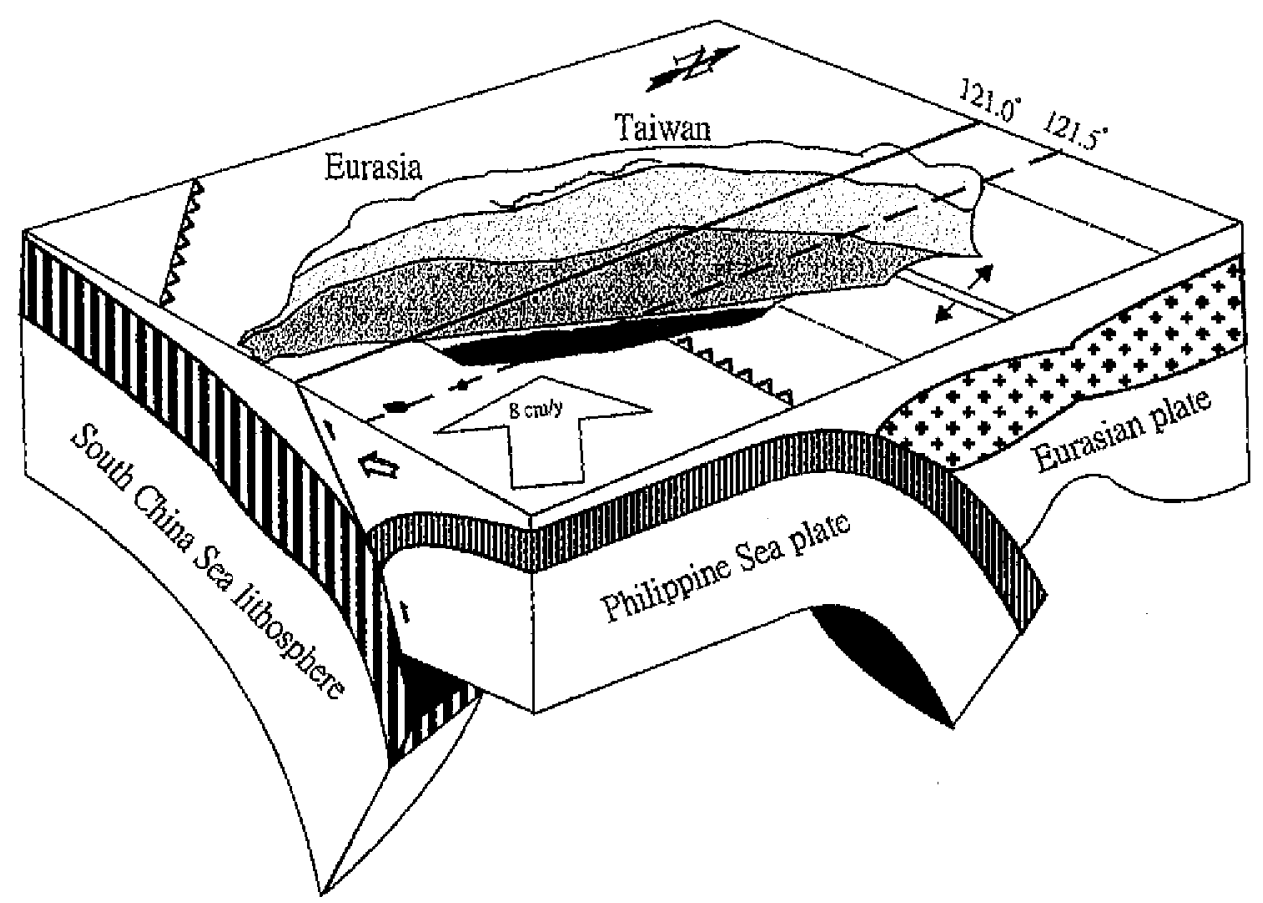

Fig. 3. Model of the lithospheric structure of the Taiwan region. The model shows the relationships among the Eurasian plate, the Philippine Sea plate and the South China Sea lithosphere; the western lithospheric boundary of the Philippine Sea plate along $121.5^{\circ} \mathrm{E}$ (dashed line); the western edge of the seismic wedge along $121.5^{\circ} \mathrm{E}$ (solid line); the area of the Okinawa trough and its center; and the starting lines of subductions along the Ryukyu and Manila trenches. The basic structure is redrawn from Angelier (1986).

The mountain building process in the Taiwan region is generally believed to be the result of an arc-continent collision (e.g., Barrier and Angelier, 1983; Suppe 1984; Teng 1990) or arcarc collision (Hsu and Sibuet 1995) on the Asian continental margin since 4 ma (e.g., Chi et al. 1981; Teng 1990; Lee and Lawver 1994). Figure 2 shows the structural provinces of Taiwan and the surrounding offshore regions. In both models, the Luzon arc and the Coastal Range play an important role. The Luzon arc has been formed from the eastward subduction of the South China Sea lithosphere along the Manila trench and is riding on the Philippine Sea plate which moves northwestward, with respect to the Eurasian plate, at a rate of about $8 \mathrm{~cm} / \mathrm{y}$ (Yu et al. 1996). In the arc-continent collision model, the Coastal Range, which is regarded as the northern part of the Luzon arc, has been colliding with the Eurasian plate, resulting in the growth of the Western Foothills and the Central Range of Taiwan through the deformation of strata and basement rocks of the Asian continental margin. The suture zone of the collision is believed to be the Longitudinal Valley in eastern Taiwan, which lies along the length of Taiwan. 
In the arc-arc collision model (Hsu and Sibuet 1995), Taiwan island has resulted from the collision of the Luzon arc with the former Ryukyu subduction zone, leaving the Hsueshan and Central Ranges on Taiwan as the uplifted portion of the backarc basin and the Longitudinal Valley as the suture zone between the Luzon arc and the former Ryukyu arc. Based on the similarities in the characteristics of the P-wave velocity structure as derived from seismic refraction experiments, it was suggested (Cheng et al. 1996) that the eastern part of the eastern flank of the Central Range and the western end of the Ryukyu arc (Fig. 2) are parts of the same tectonic unit. From their analysis of the magnetic anomaly, Shyu et al. (1996) found that the Luzon arc extends northward on the eastern side of the Coastal Range and that the northern Coastal Range is now part of the Luzon arc. Shyu et al. (1996) also indicated that north of $23.5^{\circ} \mathrm{N}$, the collision between the former Ryukyu arc (represented by the eastern part of the Central Range) and the Luzon arc (represented by the northern Coastal Range) is direct, and that south of $23.5^{\circ} \mathrm{N}$, the collision is indirect, with the uplifted sediment layers of the southern Coastal Range and its southern extension between the Luzon arc and eastern coastline of Taiwan as the buffer.

As previously stated the Luzon arc is riding on the Philippine Sea plate which moves northwestward. Therefore, both the arc-continent collision model and the arc-arc collision model only describe the surface or subsurface geological phenomena. The mountain building in the Taiwan region must directly result from the interaction of the Eurasian and the Philippine Sea plates. It may, however, also be associated with the relationship between the Ryukyu subduction and the subduction of the South China Sea lithosphere.

In this study, we shall try to delineate the boundary between the Eurasian and the Philippine Sea plates and the positions of slabs in the subduction systems, with emphasis on the tectonic environment in which the Chi-Chi earthquake occured.

\section{WESTERN BOUNDARY OF THE SUBDUCTING LITHOSPHERE OF THE PHILIPPINE SEA PLATE}

The western corner of the Philippine Sea plate is interacting vigorously with the Eurasian plate, and thus making the occurrence of earthquakes in the Taiwan region very frequent (Fig. 4). Their hypocentral distribution in the northern Taiwan area reflects the position and attitude of the subducting Philippine Sea plate, as observed in the hypocentral profiles in the N-S and E-W directions (Figs. 5 and 6). The hypocentral profiles illustrate that most earthquakes fall into one of two groups. Those earthquakes with depths of less than $40 \mathrm{~km}$ mostly fall into seismic zones, whereas those deeper than $40 \mathrm{~km}$ mainly fall within the Wadati-Benioff Zone. This zone is located east of $121.5^{\circ} \mathrm{E}$ and dips northward from about $23.5^{\circ} \mathrm{N}$ (Fig. 5). Although Figs. 5 and 6 show that the Wadati-Benioff Zone appears only to the east of $121.5^{\circ} \mathrm{E}$, there exist some scattered earthquakes deeper than $40 \mathrm{~km}$ to the west of this meridian line.

From the hypocentral distribution discussed above, it is clear that, generally speaking, the Philippine Sea plate subducts northward in the Taiwan region (Fig. 3), with the meridian line of $121.5^{\circ} \mathrm{E}$ as the surface project of the present western boundary of the active subducting lithosphere. This western boundary is situated beneath northem Taiwan, and its surface pro- 


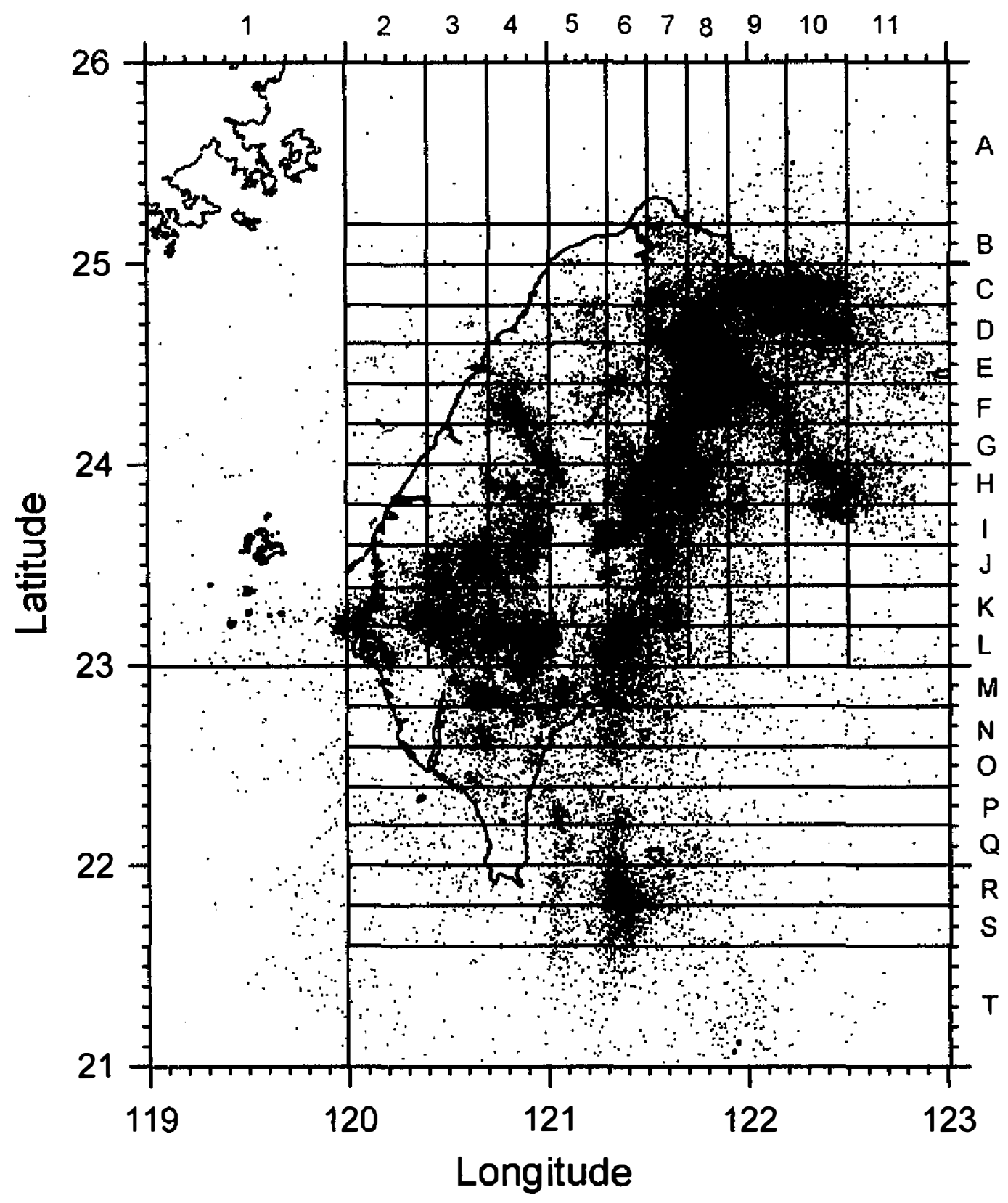

Fig. 4. Epicentral distribution of earthquakes in the Taiwan region from 1991 to 1999 (prior to the Chi-Chi earthquake). These earthquakes are used to construct the hypocentral profiles to understand the tectonic environment of the Chi-Chi earthquake and its aftershock sequence. The zones with alphabetical letters or numbers are for hypocentral profiles shown in Figs. 5 and 6. 


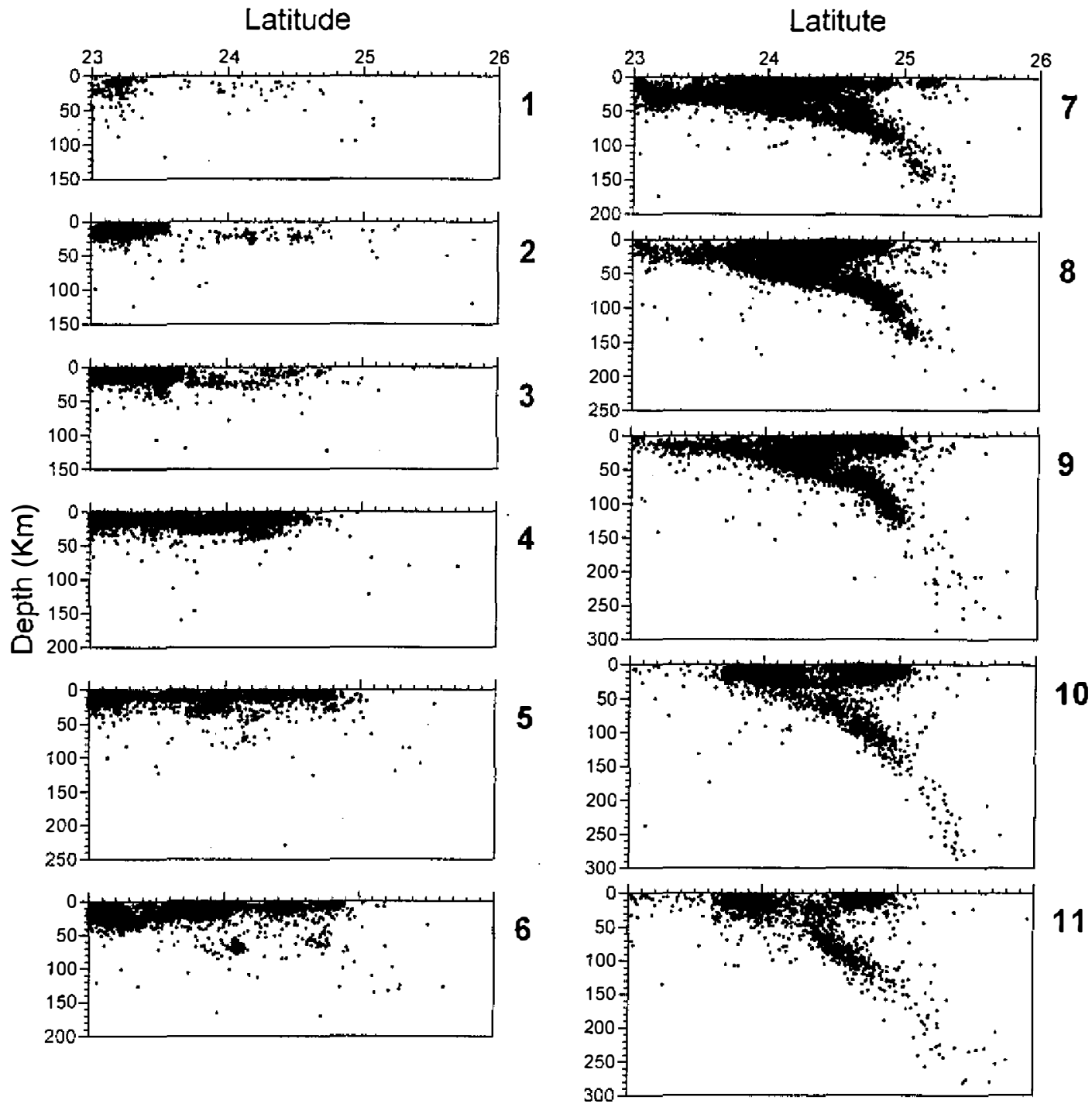

Fig.5. North-south rending hypocentral profiles for those zones shown in Fig.4.

jection line intersects the eastern coastline of Taiwan at $23.5^{\circ} \mathrm{N}$ (Fig. 3), where Shyu et al. (1996) separated the direct from the indirect collision of the Luzon arc against the Ryukyu arc. To the north of $23.5^{\circ} \mathrm{N}$, the lithosphere of the Philippine Sea plate obviously extends westward beneath Taiwan island, at least to the meridian of $121.5^{\circ} \mathrm{E}$.

According to Yu et al. (1997), the velocities of GPS stations on the two volcanic islands of Lanhsu and Lutao in the southeastern offshore area of Taiwan (Fig. 2), relative to the Paisha GPS station on one of the Penghu islands (Fig. 2), both move about $8 \mathrm{~cm} / \mathrm{y}$ in the $\mathrm{N} 5^{\circ} \mathrm{W}$ direction. This velocity represents that of the Philippine Sea plate, with respect to Eurasia, in 
Wang et al.

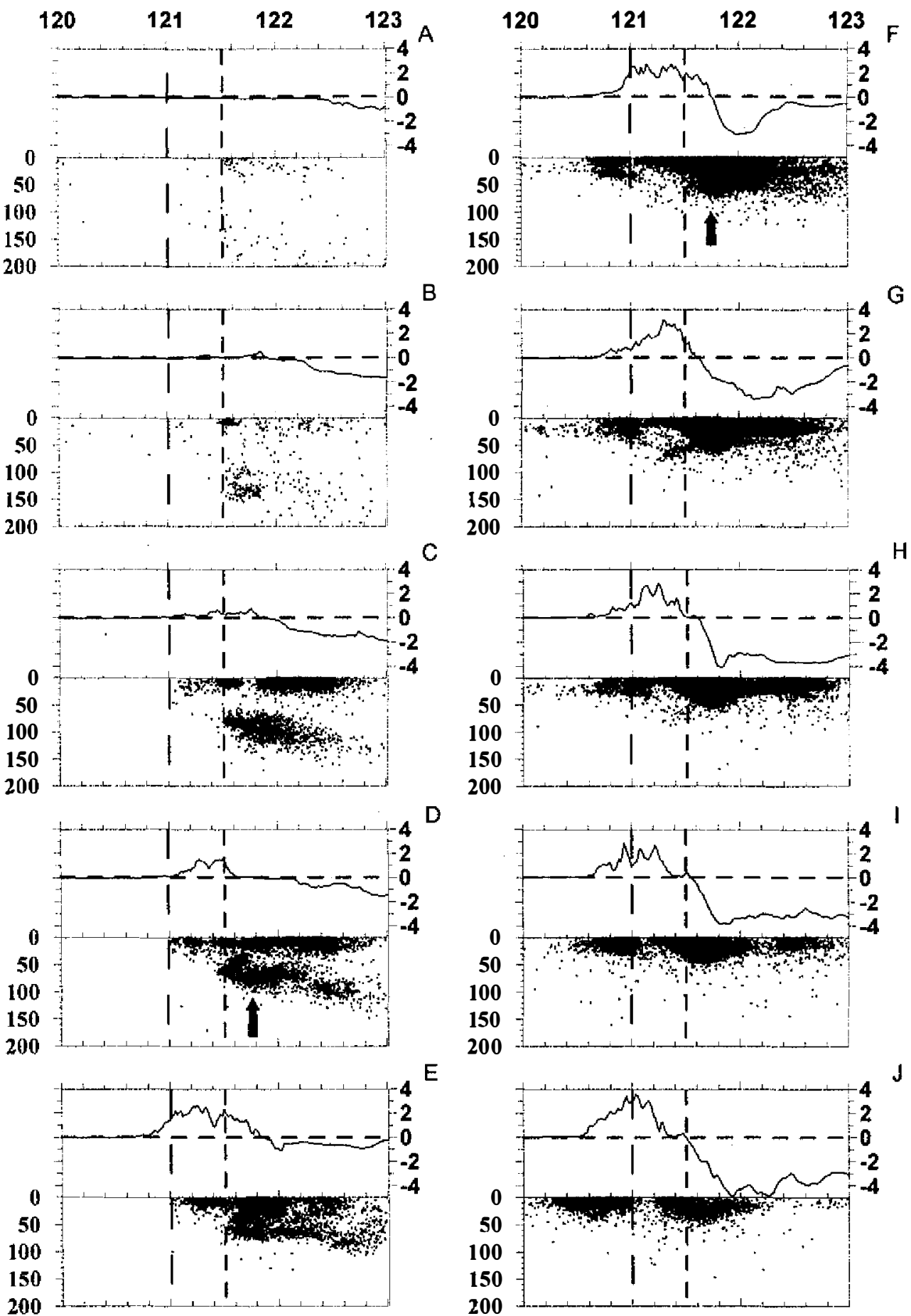

Fig. 6. East-west trending hypocentral profiles for those zones shown in Fig. 4. 

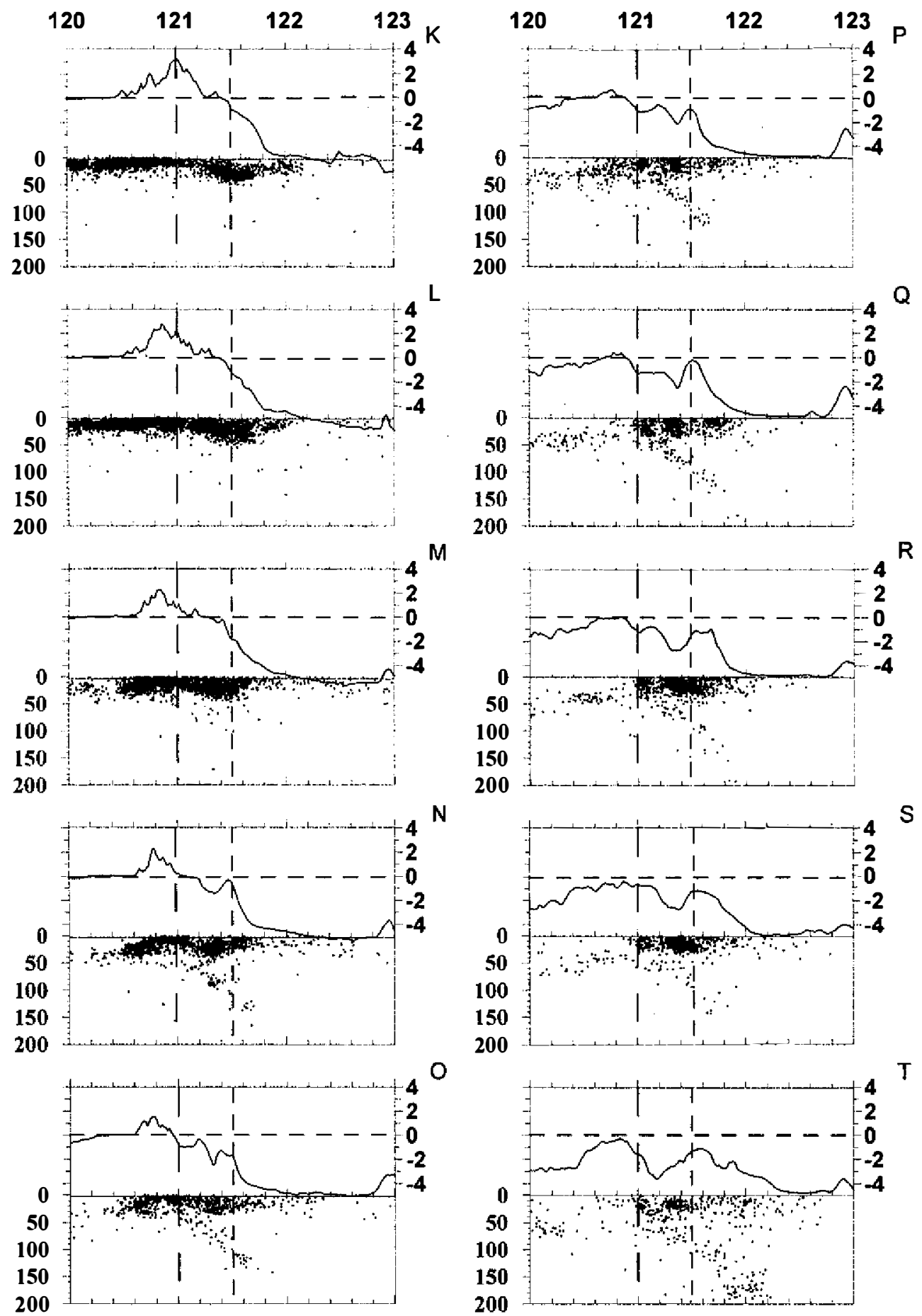

(Fig. 6. continued) 
the Taiwan region. Since the Philippine Sea plate subducts northward in the Taiwan region, its western lithospheric boundary must be migrating westward, due to the western component of its general northwestward movement. By simple calculation from the relative velocity obtained by Yu et al. (1997), we determine that the speed of the westward migration of the western lithospheric boundary of the Philippine Sea plate is about $6 \mathrm{~cm} / \mathrm{y}$.

\section{SEISMIC WEDGE NEAR THE WESTERN BOUNDARY OF THE PHILIPPINE}

\section{SEA PLATE}

In order to understand the tectonic behavior near the westward-migrating lithospheric boundary of the Philippine Sea plate beneath the Taiwan region, in this section we examine the hypocentral distribution of earthquakes near the boundary for special features associated with the mountain building process of Taiwan.

In hypocentral profiles A through $\mathrm{F}$ (north of $24.2^{\circ} \mathrm{N}$ ) in Fig. 6, the Wadati-Benioff Zone near the western lithospheric boundary of the Philippine Sea plate beneath the northern Taiwan area can be clearly seen, because the layer of earthquakes belonging to this zone (Fig. 5) is distinctly deeper in these profiles than the other near the surface. It is also evident in profiles $\mathrm{D}$ and $\mathrm{F}$ that to the east of the lithospheric boundary along $121.5^{\circ} \mathrm{E}$, the Wadati-Benioff Zone first dips westward and then warps upward at about $121.8^{\circ} \mathrm{E}$ forming a seismic wedge (as indicated by the arrow). Although the Wadati-Benioff Zone is contaminated by the earthquakes near the surface, when the hypocentral profile moves southward, the seismic wedge is present in all profiles $\mathrm{G}$ through $\mathrm{M}$ (between $24.2^{\circ} \mathrm{N}$ and $22.8^{\circ} \mathrm{N}$ ). Further southward, in hypocentral profiles $\mathrm{N}$ through $\mathrm{T}$ in Fig. 6 , the seismic wedge can no longer be clearly seen. Instead, it is separated into two groups above a clear seismic layer of earthquakes representing the South China Sea lithosphere, which dips eastward beneath the Philippine Sea plate from $121^{\circ} \mathrm{E}$. The two groups of earthquakes to the south of $22.8^{\circ} \mathrm{N}$ are distributed along the South Longitudinal Trough and the North Luzon Trough (Figs. 1, 2 and 4) in the southeastern offshore area of Taiwan, and in appearance and by location belong to the same seismic category as the seismic wedge.

\section{TECTONIC MEANING OF THE SEISMIC WEDGE}

In this section, we trace the western boundary of the seismic wedge, and try to understand its origin and tectonic meaning, by correlating its location and western boundary with the topography of Taiwan.

In the southeastern offshore area of Taiwan, between the Luzon arc and Taiwan, the South Longitudinal Trough, the North Luzon Trough and the Huatung Ridge in between (Fig. 2) mainly consist of sedimentary layers (Cheng et al. 1998), which are uplifted into the southern extension of the Coastal Range (Shyu et al. 1996). Therefore, the two seismic groups along the South Longitudinal Trough and the North Luzon Trough (Figs. 2 and 4) in hypocentral profiles $\mathrm{N}$ through $\mathrm{T}$ to the south of $22.8^{\circ} \mathrm{N}$ (Fig. 6) represent the uplifting process of the sedimen- 
tary layers in the basins above the surface of the eastward-dipping South China Sea lithosphere through the pushing or plowing by the Philippine Sea plate (Fig. 3). Near the southern end of the Coastal Range in eastern Taiwan, the two seismic groups of earthquakes between the Luzon arc and Taiwan merge forming the initial seismic wedge (hypocentral profiles $\mathrm{N}$ and $\mathrm{M}$ in Fig. 6). The western edge of this seismic wedge-to-be is along $121^{\circ} \mathrm{E}$, i.e., the eastern coastline of Taiwan.

When the hypocentral profile moves northward, to the south of $23.5^{\circ} \mathrm{N}$, it is apparent that the seismic wedge exists mainly beneath the Longitudinal Valley, the Coastal Range and the continental slope, with the western edge of the seismic wedge beneath the eastern flank of the Central Range (profiles J through M in Fig. 6). The correlation between the seismic wedge and the topography shown in profiles $\mathrm{J}$ through $\mathrm{T}$ in Fig. 6 evidently confirms the supposition of Shyu et al. (1996) and Cheng et al. (1998) that the southern Coastal Range is a compressional complex uplifted between the Central Range and the Luzon arc. Besides, since the western edge of the seismic wedge approaches the central line (i.e., the peak) of the Central Range as the hypocentral profile moves northward, it can be inferred that most of the eastern flank of the Central Range to the south of $23.5^{\circ} \mathrm{N}$ is covered or was once covered (before erosion) by the uplifted sedimentary layers between the Luzon arc (represented by the Coastal Range) and the proto-Taiwan island.

To the north of $23.5^{\circ} \mathrm{N}$, the western edge of the seismic wedge is situated near $121^{\circ} \mathrm{E}$ (hypocentral profiles A through I) and extends across the Central Range and Hsueshan Range. The seismic wedge is most prominent in profiles $G$ through $I$ (between $23.6^{\circ}$ and $24.2 \mathrm{~N}$ ). In profiles $A$ through $F$, the seismic wedge is composed of the westem end of the Wadati-Benioff Zone and some scattered earthquakes to the west of the lithospheric boundary of the Philippine Sea plate along $121.5^{\circ} \mathrm{E}$. This indicates that the seismic wedge is situated on both the Eurasian and Philippine Sea plates near the western lithospheric boundary of the Philippine Sea plate, as a result of the interaction between the plates. Figure 7 illustrates how the seismic wedge has formed. The Philippine Sea plate generally moves northwestward along $121.5^{\circ} \mathrm{E}$, meets the eastward-dipping South China Sea lithosphere or Eurasian plate lithosphere, and plows or pushes the material above the latter westward and upward along its eastward-dipping surface. The seismic wedge therefore represents the upper part of the Philippine Sea plate lithosphere (represented by the Wadati-Benioff Zone) and the wedge of the compressional complex (including the sedimentary layers, the Luzon arc and/or the already-existing mountains or mountain ranges) which is being squeezed by the pushing or plowing of the northwestward-moving Philippine Sea plate lithosphere.

\section{THE CHI-CHI EARTHQUAKE AND ITS AFTERSHOCK SEQUENCE}

The Chi-Chi earthquake was located at $120.82^{\circ} \mathrm{E}$, and $23.85^{\circ} \mathrm{N}$ with the hypocentral depth of $8 \mathrm{~km}$ and the source meters of the pure thrust type: strike: $20^{\circ}$; dip: $30^{\circ}$; rake: $85^{\circ}$ (Chang et al. 1999). It induced a tremendous number of aftershocks (Figs. 8 and 9). The hypocentral profiles (Fig. 8) show that most aftershocks were within the depth of $15 \mathrm{~km}$, except for a cluster located between 20 and $30 \mathrm{~km}$ near $121^{\circ} \mathrm{E}$ and $25.85^{\circ} \mathrm{N}$. Hence it is obvious that it can 


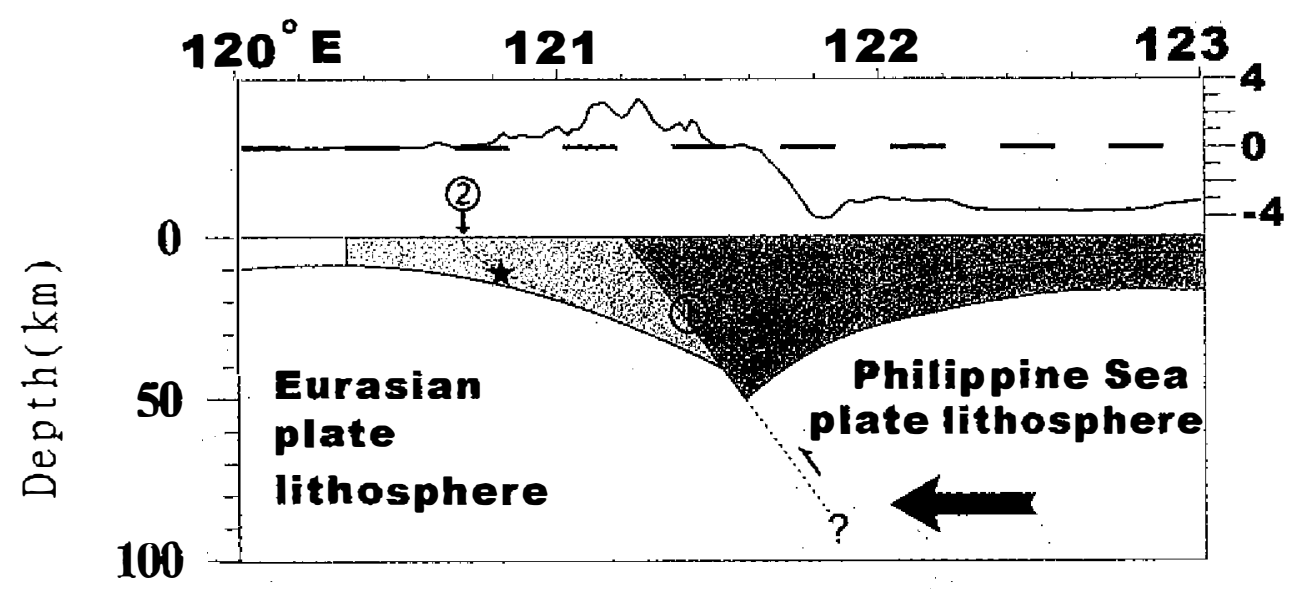

Fig. 7. Diagram showing the interaction between the Philippine Sea plate and the Eurasian plate (or South China Sea lithosphere) and the location of the seismic wedge (eastem shaded area) along $23.9^{\circ} \mathrm{N}$, which is includes the epicenter of the Chi-Chi earthquake. The diagram is drawn according to the hypocentral profile $\mathrm{H}$ in Fig. 6. For comparison, the morphological profile is shown above the diagram. Line 1 is the westem edge of the seismic wedge. Line 2 is the inferred thrust fault which caused the Chi-Chi earthquake and the extensive surface rupture' along the Chenglungpu fault. The western shaded area is a sedimentary wedge confined by the seismic wedge and the Peikang basement high, in which the Chi-Chi earthquake occurred.

be determined that all the aftershocks were crustal earthquakes near the surface. They fell into two groups: the western group and the eastern group. Those in the western group mainly formed a seismic belt striking almost north-south along the western edge of the seismic wedge (i.e., $121^{\circ} \mathrm{E}$ ), with a width of about $30 \mathrm{~km}$ and a length of about $200 \mathrm{~km}$. They were distributed mainly in the foothills and the Hsueshan Range near the western edge of the seismic wedge along $121^{\circ} \mathrm{E}$ (Figs. 2, 8 and 9). The aftershocks in the eastern group also formed a seismic belt striking about $\mathrm{N} 20^{\circ} \mathrm{E}$, with a width of about $15 \mathrm{~km}$ and a length of about $100 \mathrm{~km}$. They were distributed along the center of the Central Range to the west of the meridian line of $121.5^{\circ} \mathrm{E}$ which is the western lithospheric boundary of the Philippine Sea plate.

Based on the model of lithospheric structure in the Taiwan region shown in Fig. 3 and the diagram of interaction between the Eurasian and Philippine Sea plates (Fig. 7), the northwestward-moving Philippine Sea plate, which extends westward to $121.5^{\circ} \mathrm{E}$, pushes or plows the material in the seismic wedge westward and upward along the surface of the Eurasian plate (or the South China Sea lithosphere) dipping to the east. Near the meridian line of $121^{\circ} \mathrm{E}$, the seismic wedge, in turn, pushes or collides along its western edge with the material on the Eurasian plate, as indicated by the layer of earthquakes near the surface (Fig. 6).

In front of the seismic wedge, there are two linear seismic belts in the background seis- 


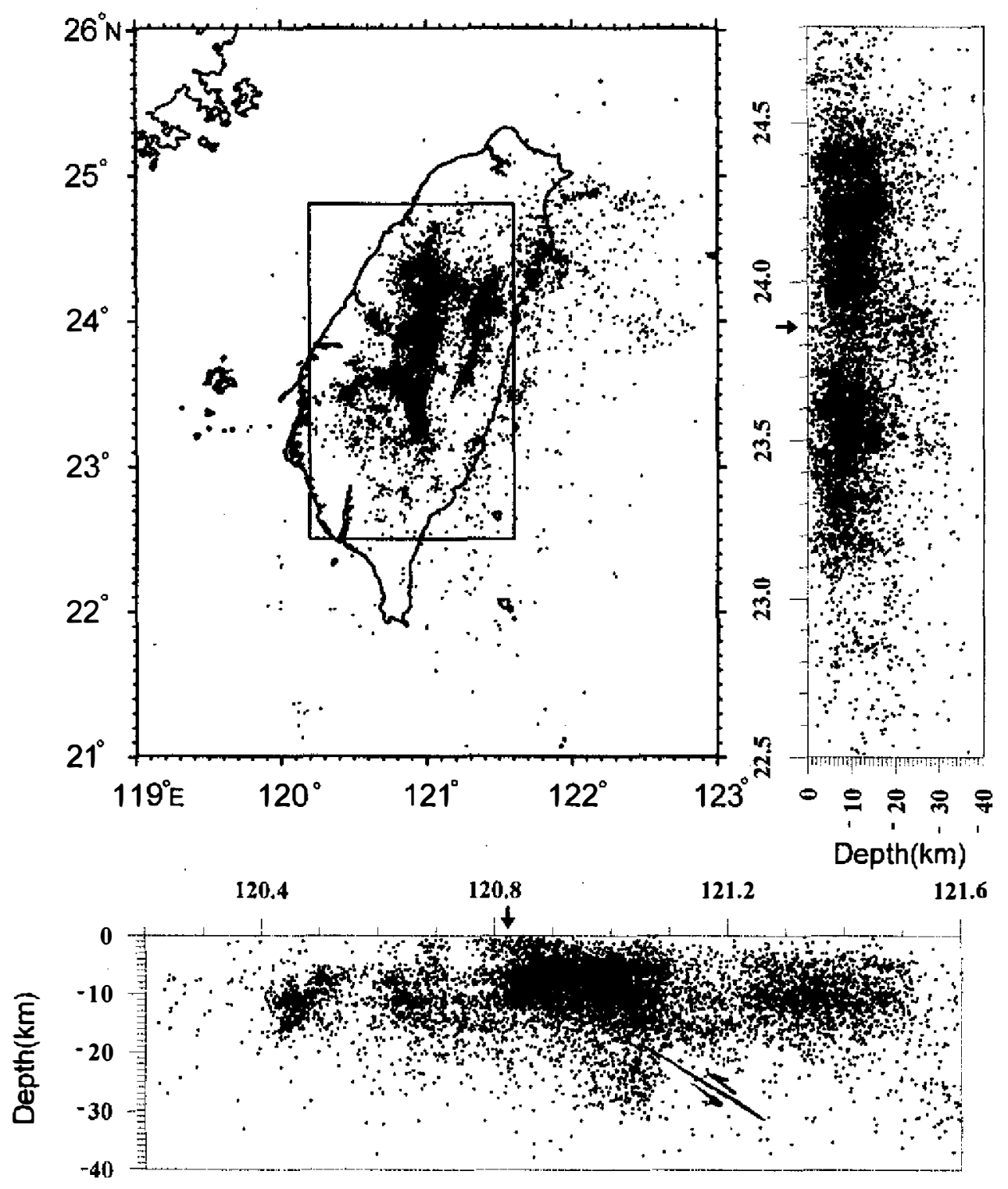

Fig. 8. Epicentral distribution of the aftershock sequence of the Chi-Chi earthquake from September 1999 to February 2000 (top-left) and the hypocentral profiles in the N-S direction (top-right) and in the E-W direction (bottom). The block in the map of epicenters shows the earthquakes used for the hypocentral profiles. The arrows directed toward the two hypocentral profiles show the epicenter of the Chi-Chi earthquake. The line with the pair of arrows in the E-W profile shows the inferred thrust fault which caused the Chi-Chi earthquake and the associated extensive ruptures along the Chelungpu fault. 


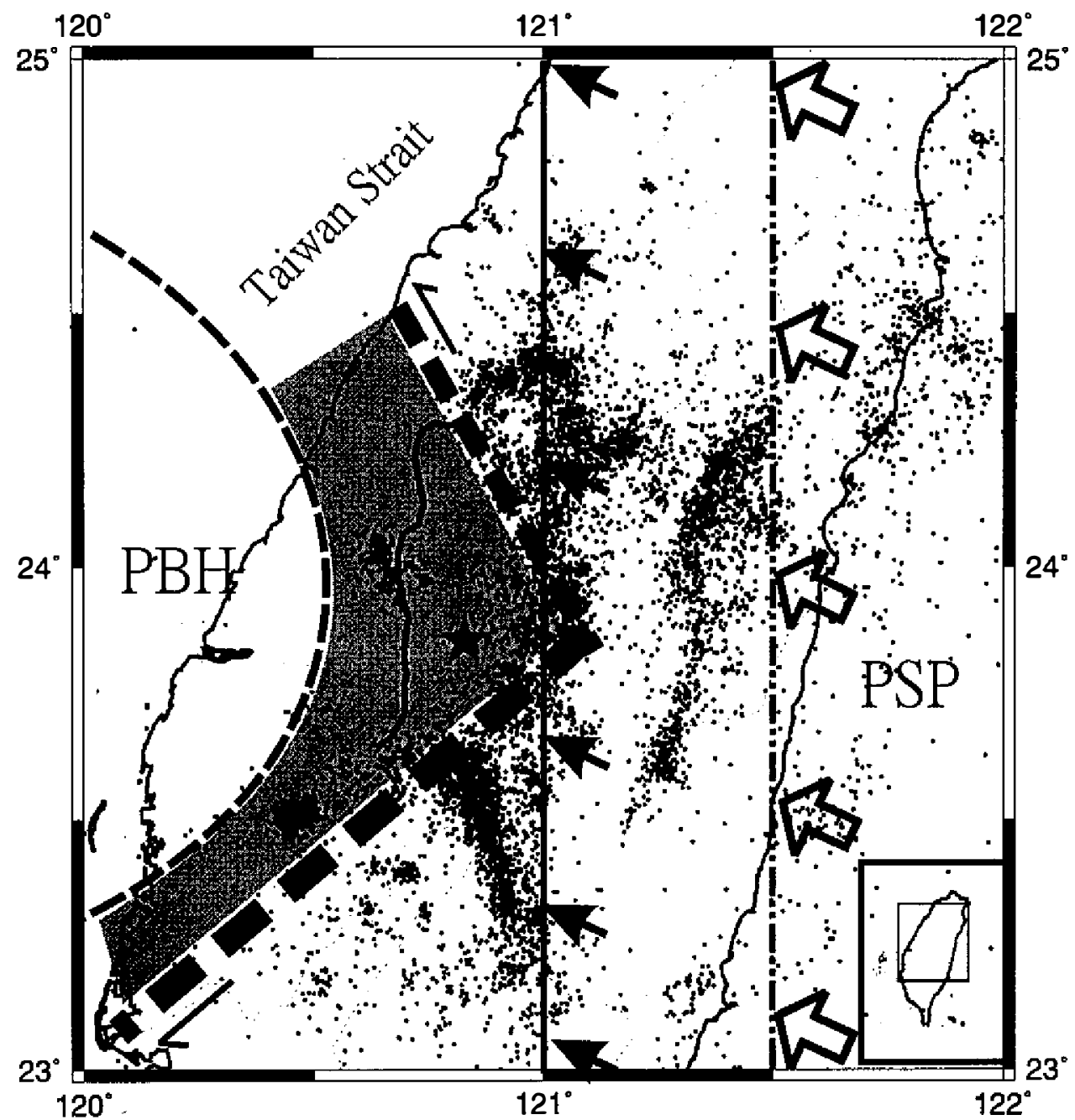

Fig. 9. Environment of the Chi-Chi earthquake (designated by the star) and its aftershock sequence. The aftershocks shown in this Figure are those with $\mathbf{M} \geq 3$. The solid line with solid arrows indicates the location of the western edge of the seismic wedge. The thin dashed line with hollow arrows indicates the trace of surface projection of the westem lithospheric boundary of the Philippine Sea plate. The arrows beside these two lines indicate the direction of stress in this area (Yen 2000). Bold dashed lines with helf-arrows indicate possible fault zones inferred from linear seismic belts. PBH: Peikang basement high; PSP: Philippine Sea plate. The shaded area indicates the area confined by the linear seismic belts (possible fault zones) and the PBH. The boundary of the PBH is drawn from the contour map of $\mathrm{P}$-wave velocity at $9 \mathrm{~km}$ in depth, as determined by the tomographic method (Huang 2000). 
micity in western Taiwan, striking NW and NE (Figs. 1 and 4). These represent two possible fault zones, left-lateral and right-lateral in sense, respectively (Fig: 10; Wang et al. 1994; Wang et al. 1996; Wang and Shin 1998; Yen 2000). These two linear seismic belts bound a triangular area with low background seismicity, including the Peikang basement high (Fig. 9), an uplifted pre-Miocene basement (Tang 1977), in the Westem Coastal Plain of Taiwan and its western offshore zone. The two linear seismic belts and the Peikang basement high further confine a subarea of the triangular area near the vertex (shaded zone in Figs. 7 and 9). The confined subarea has been pushed northwestward by the seismic wedge, but its movement has been impeded by the Peikang basement high on the western side. Accordingly, the strain energy associated with the Chi-Chi earthquake might have been stored and then released at once, which would have resulted in extensive surface ruptures, mainly along Chelungpu fault in the confined subarea. This could have also excited a tremendous number of aftershocks, as shown in Figs. 8 and 9.

For comparison with the background seismicity, we map the locations clustered with aftershocks with $M \geq 3$ (dark shaded area) and those with $M \geq 2$ (light shaded area) in Fig. 1. It is obvious that most aftershocks in the western group occurred in the sedimentary wedge (westem shaded area in Fig. 7) on the Eurasian plate in front the seismic wedge. This sedimentary wedge is the site of background seismicity and of historically destructive earthquakes. The aftershocks of the Chi-Chi earthquake in the western group filled the sedimentary wedge in western Taiwan, in front of the seismic wedge, all the way from $22.9^{\circ} \mathrm{N}$ to $24.7^{\circ} \mathrm{N}$, including all the areas with low seismicity and seismic gaps (Fig. 1). Similarly, the aftershocks in the eastern group filled the whole zone about $15 \mathrm{~km}$ wide to the west of the Noutheastern Coastline Seismic Belt (NCSB)(Wang et al. 1994), where seismicity is much lower than that in the NCSB (Figs. 1 and 4).

\section{CONCLUSIONS}

In this paper, we have examined the characteristics of the hypocentral distribution of earthquakes in the Taiwan region for detailed tectonic structures concerning the interaction between the Eurasian and Philippine Sea plates, with emphasis on the tectonic cause of the 1999 Chi-Chi earthquake in central Taiwan and its aftershock sequence. We have reached the following conclusions:

(1) Due to its general northwestward movement and the impediment of its motion, the Philippine Sea plate subducts northward and underthrusts westward in the Taiwan region, with the western lithospheric boundary of the plate along the meridian line of $121.5^{\circ} \mathrm{E}$. The lithospheric boundary is beneath the northern Taiwan area north of $23.5^{\circ} \mathrm{N}$ and the southeastem offshore area of Taiwan south of this latitude. It is migrating westward at a rate of about $6 \mathrm{~cm} / \mathrm{y}$, along with the northwestward movement of the Philippine Sea plate.

(2) There exists a seismic wedge (clustered with earthquake hypocenters) near the western lithospheric boundary of the Philippine Sea plate, with the vertex near the lithospheric boundary and the western edge near the meridian line of $121^{\circ} \mathrm{E}$. The seismic wedge indicates that the lithosphere of the Philippine Sea plate, like a plow, pushes westward and uplifts a wedge 
of material, near the lithospheric boundary, along the surface of the Eurasian plate lithosphere (or the South China Sea lithosphere) dipping to the east. The seismic wedge, in turn, pushes the material beneath western Taiwan along its western edge, thereby making a sedimentary wedge with seismicity - the site for historical earthquake events in western Taiwan.

(3) There are two linear seismic belts in western Taiwan, striking NW and NE. These belts along with the Peikang basement high, an uplifted pre-Miocene basement beneath the Western Coastal Plain of Taiwan and its offshore zone, confine a small triangular area in central western Taiwan with low background seismicity in front of the seismic wedge. The northwestward movement of this small confined area has long been impeded by the Peikang basement high. In such a way, the strain energy associated with the 1999 Chi-Chi earthquake in central Taiwan might have been stored and then released as the Chi-Chi earthquake and caused instantaneous and extensive rupturing, mainly along the Chelungpu fault, in the confined area. The Chi-Chi earthquake also excited a tremendous number of aftershocks, most of which fell into one of two seismic belts along the western edge of the seismic wedge and along the center of the Central Range near the lithospheric boundary of the Philippine Sea plate.

Acknowledgments The authors would like to thank the Seismological Observation Center, Central Weather Bureau of the Republic of China (Taiwan) and the Institute of Earth Sciences, Academia Sinica (Taipei, Taiwan) for making available the seismological data of the Taiwan region. This research was supported by the National Science Council of the Republic of China (Taiwan).

\section{REFERENCES}

Angelier, J., 1986: Preface to the special issue of Geodynamics of the Eurasian-Philippine Sea plate boundary. Tectonophysics, 125, IX-X.

Barrier, E., and J. Angelier, 1983: Active collision in eastern Taiwan: the Coastal Range. Memoir Geol. Soc. China, 7, 135-159.

Cheng, W. B., C. Wang, and C. T. Shyu, 1996: Crustal structure of the northeastern Taiwan area from seismic refraction data and its tectonic implications. TAO, 7, 467-487.

Chung, J. K., and T. C. Shin, 1999: Implications of the rupture process from the displacement distribution of strong ground motions recorded during the 21 September, 1999 ChiChi, Taiwan earthquake. TAO, 10, 777-786.

Chi, W. R., J. Namson, and J. Suppe, 1981: Stratigraphic records of plate interactions in the Coastal Range of eastern Taiwan. Memoir Geol. Soc. China, 4, 15-194.

Ho, C. S., 1986: A synthesis of the geologic evolution of Taiwan. Tectonophysics, 125, 1-16.

Ho, C. S., 1988: An introduction to the geology of Taiwan, 2nd ed., Central Geological Survey, The Ministry of Economic Affairs, Taipei, 192 pp. (in Chinese)

Hsu, S. K., and J.-C. Sibuet, 1995: Is Taiwan the result of arc-continent or arc-arc collision?, Earth Planet. Sci. Lett., 136, 315-324. 
Huang, J. H., 2000: 3-D structure of wave velocities and Vp/Vs in the southern Taiwan area and their implications in tectonics and oil exploration. Master Thesis, Institute of Applied Geophysics, National Taiwan Ocean University.

Lee, C. F., C. H. Hou, T. C. Lin, and T. C. Lai, 1999a: The Chelungpu fault and the 199921 September, Taiwan earthquake. 7-36 (in Chinese).

Lee, T.Y., and L.A. Lawver, 1994: Cenozoic plate reconstruction of the South China Sea region. Tectonophysics, 235, 149-180.

Lee, Y. H., W. Y. Wu, S. D. Lu, T. S. Shih, M. L. Hsieh, W. C. Huang, C. Y. Chen, H. J. Chen, C. W. Lin, and C. C. Chang, 1999b: Investigation into ruptures along the Chelungpu fault in western Taiwan. Investigative Report on the 1999 September 21 Chi-Chi, earthquake in central Taiwan (published by the Central Geological Survey of Taiwan), 1021 (in Chinese).

Liu, C. C., I. H. Su, C. H. Hou, C. F. Lee, and T. C. Lai, 1999: Co-seismic and post-seismic deformation caused by the 1999 September 21 Chi-Chi earthquake in central Taiwan. National Science Newsletter of the National Science Council of Taiwan, 156-161 (in Chinese)

Rau, R. J., J. Y. Yu, T. T. Yu, M. Yang, and C. L. Tseng, 1999: Co-seismic displacements of the 1999 Chi-Chi, Taiwan earthquake sequence. AGU 1999 Fall Meeting Program, p. 15.

Shyu, C.T., M.C. Chih, S.K. Hsu, C. Wang, and B. Karp, 1996: Northern Luzon arc: location and tectonic features from magnetic data of eastern Taiwan. TAO, 7, 535-548.

Suppe, J., 1984: Kinemetics of arc-continental collision, flipping of subduction, and back-arc spreading near Taiwan. Memoir Geol. Soc. China, 6, 21-33.

Tang, C. H., 1977: Late Miocene erosional unconformity on the subsurface Peikang high beneath the Chiayi-Yunlin coastal plain, Taiwan. Memoir Geol. Soc. China, 2, 155168.

Teng, L.S., 1990: Geotectonic evolution of late Cenozoic arc-continent collision. Tectonophysics, 183, 57-76.

Wang, C., H. F. Huang, J. T. Shin, Y. L. Liu, Y.M. Wu, H. Y. Yen, and W. C. Liang, 1994: A study of the distribution pattern of earthquakes occuring during 1991-1993 in the Taiwan region, Technical Report of the Seismological Observation Center. Ministry of Communications, 8-1, 243-271 (in Chinese).

Wang, C. Y., and T. C. Shin, 1998: Illustrating 100 years of Taiwan seismicity. TAO, 9, 589614.

Wang, C., A. S. Svarichevsky, C. F. Huang, and S. L. Wang, 1996: A strike-slip fault system trending NE in and around the northwestern corner of the West Philippine Basin. TAO, 7, 489-503.

Yen, I. C., 2000: A background stress and tectonic study of the seismogenic zone of the 1999 September 21 Chi-Chi earthquake in central Taiwan. Master Thesis, Institute of Applied Geophysics, National Taiwan Ocean University.

Yu, S. B., H. Y. Chen, and L. C. Kuo, 1997: Velocity field of GPS stations in the Taiwan area. Tectonophysics, 274, 41-59. 